\title{
Training of Lemuru Fish Nuggets Processing for Stunting Children's Mothers in Pantai Labu Sub-District Deli Serdang Regency
}

\author{
Dini Lestrina*, Novriani Tarigan, Oslida Martony \\ Nutrition Department, Politeknik Kesehatan Kementerian Kesehatan Medan, Indonesia
}

\begin{abstract}
Failure of stunting in children will produce human resources that cannot compete in the era of globalization, affect work productivity, increase the risk of obesity, and lead to metabolic syndrome. Indonesia has a high incidence of stunting among children under five and school children, including North Sumatra with a prevalence of $42.3 \%$, ranked fourth in the province with a high stunting prevalence. The prevalence of stunting in children aged 5-12 years increases every year. During the growth of very high bone mineralization, low intake of protein, calcium, and zinc influences linear growth. Aged 5-12 years is an opportunity to catch up and improve height. In terms of overcoming the lack of protein, calcium, and zinc intake as well as spurring the growth of schoolchildren, it can be done by giving Lemuru fish nuggets. Fish nugget processing is a simple processing method and has a long shelf life, with storage life in the freezer was 2 weeks. From the results of conseling and training conducted an initial and final knowledge assessment, it is known that initial knowledge is still lacking with an average value of 64.69 after the activity has increased to 83.95. Participants better understand the benefits of local food such as lemuru fish to cope with the stunting situation experienced by their child.
\end{abstract}

Keywords: Training, Lemuru fish nugget, Children, Stunting

Abstrak. Kegagalan pertumbuhan Tinggi Badan (stunting) pada anak akan menghasilkan sumber daya manusia yang tidak dapat bersaing di era globalisasi, mempengaruhi produktivitas kerja, meningkatkan resiko kegemukan dan memicu penyakit sindrom metabolik. Indonesia memiliki kejadian stunting pada balita dan anak sekolah yang cukup tinggi, termasuk Sumatera Utara dengan prevalensi 42,3\%, peringkat keempat provinsi dengan prevalensi stunting tinggi. Prevalensi stunting pada anak sekolah usia 5-12 tahun meningkat setiap tahunnya. Selama masa pertumbuhan mineralisasi tulang sangat tinggi, rendahnya asupan protein, kalsium *Corresponding author at: Politeknik Kesehatan, Medan, Indonesia

E-mail address: dinilestrina@gmail.com

Copyright (C) 2018 Published by Talenta Publisher, ISSN: 2621-4830

Journal Homepage: https://talenta.usu.ac.id/jst 
dan zink mempengaruhi pertumbuhan linear. Usia 5-12 tahun merupakan kesempatan untuk memperbaiki tinggi badan. Dalam hal penanggulangan kekurangan asupan protein, kalsium dan zink serta memacu kejar pertumbuhan anak sekolah dapat dilakukan dengan pemberian nugget ikan lemuru. Pengolahan nugget ikan merupakan cara pengolahan yang sederhana dan mempunyai daya tahan simpan yang cukup lama, dengan penyimpanan dalam freezer bisa mencapai 2 minggu. Dari hasil penyuluhan dan pelatihan dilakukan penilaian pengetahuan awal dan akhir, diketahui pengetahuan awal masih kurang dengan nilai rata-rata 64,69, setelah kegiatan mengalami peningkatan menjadi 83,95. Peserta lebih memahami manfaat pangan lokal seperti ikan lemuru untuk dapat menanggulangi keadaan stunting yang dialami anak mereka.

Kata Kunci: Pelatihan, Nugget ikan lemuru, Anak, Stunting

Received 20 March 2020 | Revised 15 April 2020| Accepted 27 April 2020

\section{Introduction}

Currently, Indonesia still has many cases of lack of nutrition in children and school-age, which could affect children's growth, development, and nutritional status. School-age children are vulnerable to get unbalanced nutritional intakes, which could increase the risk of reach the standard number height/stunting. In the long-term stunting couldaffect work productivity, risk of obesity, as well as metabolic syndrome disease.

Stunting could stem from lack of food intake, the ability of the household to provide adequate quantities and types of food, the nutritional care of mothers and children, educational and behavioral factors, and the health condition of household members [2].

The quantity and quality of protein intake affect the plasma levels of insulin growth factor I (IGF-I) and also on bone matrix proteins as well as growth factors that play an important role in bone formation. Besides, the fulfillment of some micronutrientsintake has a very important role to prevent stunting and promote the child's linear growth such as zinc, iron, vitamin A, iodine, even calcium and phosphorus [3]. A study proved that a low ratio of body height/age (BH/A) is caused by low protein intake and low consumption of iodine and zinc [4]. Sari et al [5] also showed that the intake of micronutrients in children stunting significantly lower than normal children. Growth failure can be caused by malabsorption of one or more nutrients such as micronutrient intake of calcium and zinc [6].

The results of the research show the prevalence of short body in North Sumatra in 2007, 2010, and 2013 in the participating are 36.8\%, 35.6\%, and 37.2\%, and North Sumatra is the 8 th of the 20 provinces in Indonesia which has a high prevalence of short bodies [7]. 
Providing intervention in the form of interlude food that meets the nutritional needs of stunting children can be used to solve the nutrition problem. Optimizationof nutritional problem-solving in children can be done through diversification in the development of dietary intake formula by considering nutritional aspects, health benefits, acceptability, and the benefits of local food resources [8].

In terms of countermeasures to overcome the lack of protein, calcium, and zinc intake as well as spurring the growth of schoolchildren, the administration of Lemuru fish nuggets will be done. Fish nugget processing is a simple processing method and can be stored in the freezer for 2 weeks.

Pantai Labu Sub-District is one of the coastal areas producing fish, and Lemuru fist is one of the fish types that is commonly found, has a cheap price, and easily obtained by the community. However, Lemuru fish is only sold in fresh form and there is no processing to increase its utilization and added value.

Lestrinaet al. [9] found that stunting rates were quite high in 3 State Primary Schools in the Pantai Labu Public Health Center, Deli Serdang Regency, SDN 104258 at 29.4\% (20 people from 68 students), SDN 105336 Rantau Panjang by 29.5\% (14 people from 44 students) and SDN 105344 Denai Lama by 36\% (18 people from 50 students). Lestrina et al. [9] also found that an intervention can be used to overcome the stunting problem in these elementary schools by providing interlude food made in the form of lemuru fish Nugget for 30 days. The intervention results showed a faster increase in height in the group of stunted elementary school 1 children who were given lemuru fish nuggets (treatment group) compared to elementary school children 1 grade who were not given lemuru fish nuggets (control group). The results of the study prove that the increase in the average $\mathrm{Z}$ increase in $\mathrm{TB} / \mathrm{U}$ scores for grade 1 elementary school students who were given lemuru nuggets for 30 days by 0.08 , while elementary school children who were not given grade 1 experienced an average increase in $\mathrm{Z}$ score of 0.01 . Based on this background, it is necessary to conduct training activities on Lemuru fish nugget processing for mothers of elementary school children who have been stunted, so that they can continue feeding interludes after the intervention activities have been completed for 30 days. This is because based on the results of interviews the children have a tendency to less like consuming fish in its original form, but if fish are processed in the form of current food trends such as fish nuggets, then fish consumption will be higher. 
The objectives of this community service are: 1) to increase knowledge of mothers who have stunting children about nutritional problems experienced by their children; 2) to increase mother's knowledge about the use of local food to overcome nutritional problems experienced by her child, and 3) to improve the skills of mothers to use local food, such as lemuru fish in the form of nuggets to increase fish consumption in children.

\section{Methods}

The target audience in this community service activity are mothers who have stunting children in the Labu Pantai Puskesmas working area which includes 31 elementary schools, both public and private. In this community service activity, the target society was determined that mothers who had stunting children from 2 public elementary schools (SDNs), SDN 104258 Pematang Biara and SDN 105336 Rantau Panjang. Both of these SDNs have 31 first-grade elementary school students who were stunted in 2018. The location of community service activities was carried out at the Office of the Pematang Monastery Village Head and Labu Pantai Health Center Hall. The choice of location is because it is an adjacent building for the two SDNs, has a yard, a fairly large room, and facilities that meet the implementation of counseling activities and food processing demonstrations.

This community service activity was carried out for 2 months with several steps of activities:

1. Explanation of activities to be carried out to target audiences.

2. Pre-test activities to find out the initial knowledge of the target audience about stunting. This activity is carried out in the first week.

3. Counseling about stunting in the second week

4. Counseling about the use of fish to overcome stunting, in the third week

5. Training on making lemuru nuggets using demonstration method, on the third week

6. Post-test activities to find out the final knowledge of the target audience about stunting in the fourth week.

7. Evaluation of the understanding of the target community is carried out 2 times, one week before the activity ends and two weeks later after the activity ends. The evaluation was carried out by filling out the questionnaire to the target audience and nutrition workers in Labu Pantai Health Center. 


\subsection{Training of lemuru fish nugget processing}

The materials used in the making of lemuru fish nuggets (Figure 1) are as follows: $60 \mathrm{~g}$ of fresh lemuru fish then the scaly and gill were cleaned, $50 \mathrm{~g}$ mashed tofu, $25 \mathrm{~g}$ of fresh carrots that cut into small pieces, $20 \mathrm{~g}$ of chicken eggs, $10 \mathrm{~g}$ of milk powder, $35 \mathrm{gof}$ wheat flour, 4 pcs of garlic, 1 table spoon chopped green onion and celery, $1 / 2$ tea spoon pepper, crumb bread, 1 cup of vegetable oil and $1 / 2$ teaspoon salt.

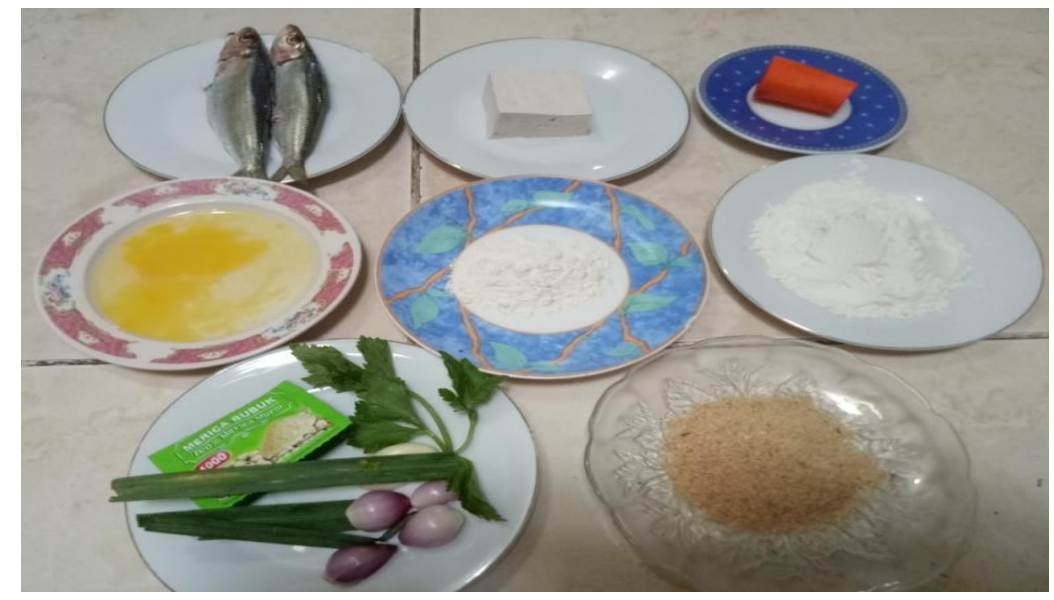

Figure 1. The material in making fish lemuru nugget

The process of making lemuru fish nuggets is as follows: fish that have been cleaned boiled in a pressure cooker for 1 hour until all of the fish's parts have softened (Figure 2A). Carrots, tofu, shallots, mashed garlic are put into the fish mixture, and mixed, then flour, eggs, milk powder, ground pepper, sliced scallions, and celery were added into the mixture, and stirred until the smooth fish dough was obtained (Figure 2B). The dough is placed on a baking pan that has been smeared with oil, then steamed until cooked. Cooked dough is cooled, then cut to a uniform size. The piece of dough is dipped in egg white, then dredge in bread crumb mixture (Figure 2C), and fried in hot oil until it is brownish yellow.

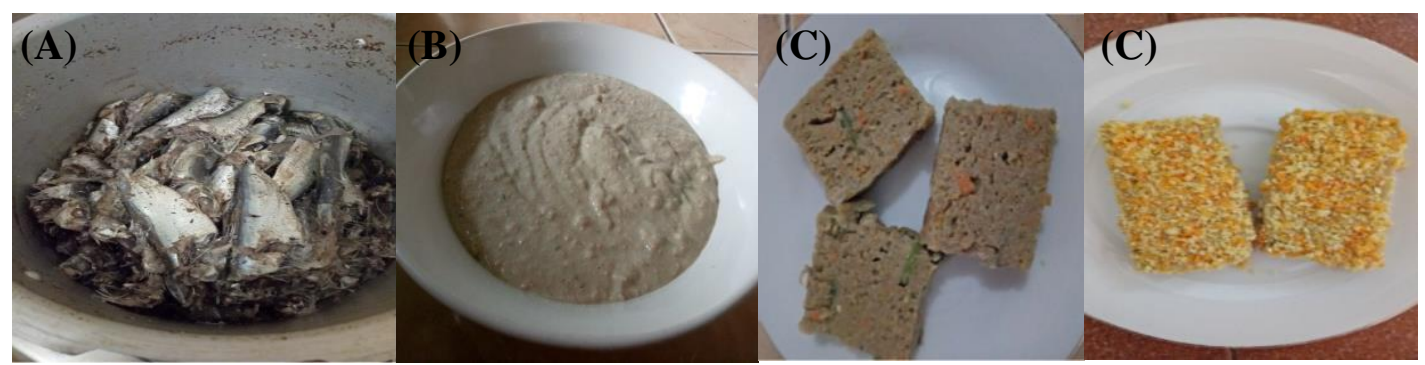

Figure 2. (A) The softened lemuru fish; (B) The smooth fish dough; (C) Fish nugget before (left) and after (right) dredge in bread crumb mixture 


\subsection{Evaluation of the activity}

Evaluation of this activity is carried out by asking closed questions (questionnaires) to the target audience, this is done at the beginning and end of community service activities. Further evaluation is done by asking questions in the form of interviews with nutrition workers at the Pantai Labu Health Center. This evaluation was conducted in the fourth week after the community service activities ended.

\section{Results and Discussions}

\subsection{Location Description}

Pantai Labu Puskesmas is a public health centrethat has a working area in one Pantai Labu sub-district, which is located at Pantai Labu Pekan street, Pantai Labu Sub-District, Deli Serdang Regency. The working area is $\pm 8,185$ Ha. Pantai Labu Puskesmas was established in 1974, and in October 2008 Pantai Labu Puskesmas was formalized as an inpatient Puskesmas.

Pantai Labu Sub-District is an area located on the coast with territorial boundaries:

- Northside is bordered by Percut Sei Tuan / Batang Quiz

- Eastside is bordered by the Malacca Strait

- Westside is bordered by Mirror Beach

- Southside is bordered by Beringin District

Lemuru is a widely sold fish with the average price of around $\mathrm{Rp} .5,000 / \mathrm{kg}$, but rarely consumed local people and mostly considered for domestic cats' food. One of the reasons is because lemuru does not have thick meat and has lots of thorns. Lemuru contains similar nutrients with other higher price fishes.

\subsection{Extension Activity}

This community service activity began with socialization by visiting the Head of the Labu Pantai Health Center and Nutrition Workers (TPG). The training participants were mothers of children in 2 SDNs who had stunted children based on the results of previous studies. The characteristics of the participants can be seen in Table 1 . 
Table 1. Distribution of Training Participants by Characteristics

\begin{tabular}{lrc}
\hline Characteristics & $\mathrm{n}$ & $\%$ \\
\hline a. Age & & \\
20-29 years & 9 & 29,0 \\
30-39 years & 14 & 45,2 \\
40-49 years & 8 & 25,8 \\
& & \\
b. Education & 11 & 35,5 \\
Primary School & 10 & 32,3 \\
Junior High School & 10 & 32,3 \\
High School & & \\
& & \\
c. Profession & 28 & 90,3 \\
Housewife & 1 & 3,2 \\
Enterpreneurs & 1 & 3,2 \\
Trader & 1 & 3,2 \\
Employee & 31 & 100 \\
\hline \multicolumn{1}{c}{ Total } & &
\end{tabular}

Table 1 shows that the majority of mothers are 30-39 years old with elementary, junior high and high school education, and were housewives. The characteristics of these participants make it possible to carry out the results of this training later because participants have enough time to do food processing in the family and are mothers who always provide family food. Some grade 1 elementary school children who have stunting status can be seen in Figure 3.

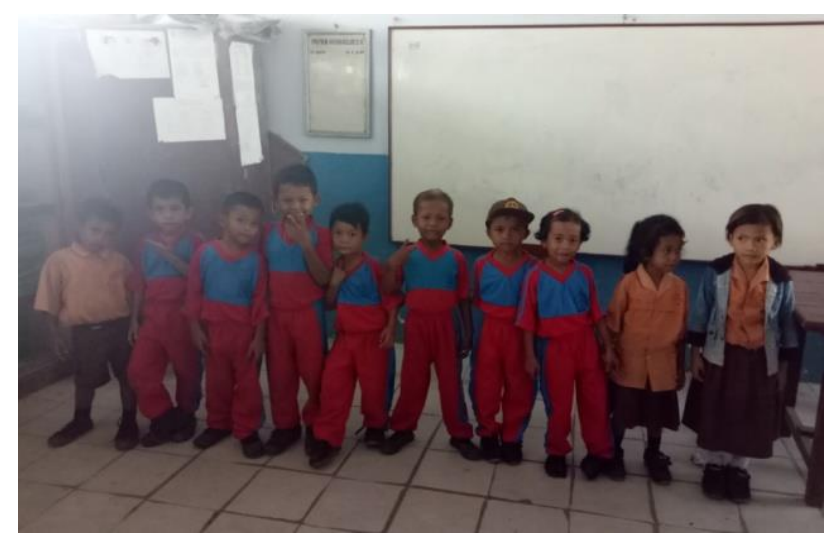

Figure 3. Some children of Grade 1 at Elementary School with short BH/A status (stunting)

The extension activities carried out were counseling about stunting and the benefits of fish for stunting children. Initial counseling was carried out in the office of Pematang Biara Village. Before the counseling activities, 15 questions pre-test was conducted to find out the trainees' initial knowledge about stunting. The results show that only seven mothers $(22.6 \%)$ can correctly answer what is meant by stunting, 14 mothers $(45.2 \%)$ 
know the benefits of calcium and 17 mothers (54.8\%) know about balanced menus for children.

This shows that the most of mothers do not yet know that they have children with a short status that must be increased in height. One way that can be done to increase children's height is by using lemuru fish nugget as interlude food. The counseling activities (Figure 4) are carried out at the end of school hours when mothers pick up children from school. Participants can participate in extension activities until completion. There were several questions raised by the participants, such as about the benefits of fish bones and bones which were used entirely in making nuggets, the problem of difficult children who were less willing to consume fish, and how to process fish until the bones and thorns became soft.

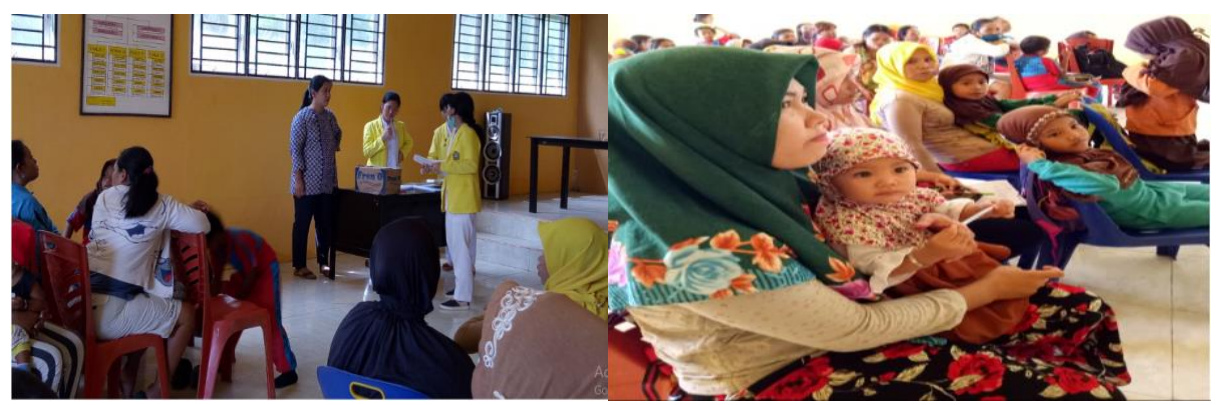

Figure 4. Extension activity

\subsection{Training of lemuru fish nugget making}

A variety of fish processing is needed especially if it will be given to children because they generally prefer processed food products such as meatballs, sausages, and nuggets. This can also be seen from the increasing number of sales of the product, including in the school environment. From the result of the previous study [9], it is known that children like lemuru fish nugget and eat the nugget every day without complaints of boredom. In this community service, the participant was provided the training about lemuru fish nugget making and continued with the practice directly in the form of cooking demonstrations in front of the trainees (Figure 5).

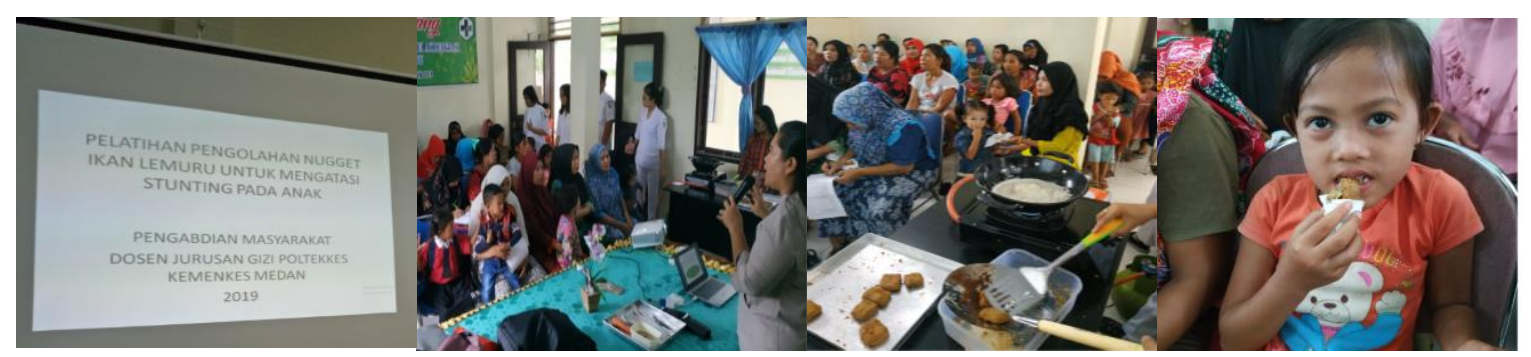

Figure 5. Participant of training and demonstration activity of lemuru fish nugget 
During the training and cooking demonstration, the participants were very enthusiastic and actively asked questions. According to the training participants, lemuru fish nuggets made have advantages because the composition is not only fish but combined with carrots and tofu to reduce the fishy aroma of the nugget. Children who taste the nuggets give the respond "like" to the given nuggets. However, based on the results of the discussion it was found that not all participants had a pressure cooker in their homes. Therefore, the training team provided a solution by boiling fish in a covered pot with low heat. This method also produces softened fish including the spines and bones but requires a longer cooking process.

The nutritional composition of the lemuru nuggets was then analyzed. Table 2 shows that the lemuru fish nugget contains $9.33 \%$ protein, which is still below the SNI standard [10] chicken nugget protein levels of at least $12 \%$. This is because all parts of the lemuru fish are used including bones and spines, thus so that it will reduce the use of fish meat and decrease the protein content of the product. Meanwhile, the mineral content $(\mathrm{Ca}, \mathrm{Mg}, \mathrm{Fe}, \mathrm{Zn}$, and, $\mathrm{P})$ of lemuru fish nugget is higher.

Table 2. Nutrition composition of lemuru fish nugget per $100 \mathrm{~g}$

\begin{tabular}{clccc}
\hline No & \multicolumn{1}{c}{ Parameter } & Unit & Amount & Analysis Method \\
\hline 1 & Moisture Content & $\%(\mathrm{~b} / \mathrm{b})$ & 60.0 & SNI 01-2891-1992 \\
2 & Ash Content & $\%(\mathrm{~b} / \mathrm{b})$ & 14.9 & SNI 01-2891-1992 \\
3 & Protein & $\%(\mathrm{~b} / \mathrm{b})$ & 9.33 & SNI 01-2891-1992 \\
4 & Carbohydrate & $\%(\mathrm{~b} / \mathrm{b})$ & 10.7 & SNI 01-2891-1992 \\
5 & Total Fat & $\%(\mathrm{~b} / \mathrm{b})$ & 3.88 & SNI 01-2891-1992 \\
6 & Phosphorous (P) & $\%(\mathrm{~b} / \mathrm{b})$ & 0.39 & Spectrophotometry \\
7 & Zinc (Zn) & $\mathrm{mg} / \mathrm{kg}$ & 20.9 & AAS* \\
8 & Calsium $(\mathrm{Ca})$ & $\mathrm{mg} / \mathrm{kg}$ & 1217.6 & AAS* \\
9 & Magnesium $(\mathrm{Mg})$ & $\mathrm{mg} / \mathrm{kg}$ & 120.7 & AAS* \\
10 & Iron (Fe) & $\mathrm{mg} / \mathrm{kg}$ & 13.1 & AAS* \\
\hline *AAS & Atomic Absorption Spectrophotometry & &
\end{tabular}

\subsection{Impact of the training activity}

The impact of the training is evaluated by comparing as answers of the 15 questions of the pre and posttests. The pretest was conducted before the extension activities were carried out, while the posttest was conducted after the completion of the training activities for lemuru fish nugget processing. The results can be seen in Table 3 . 
Table 3. Distribution of participants' knowledge categories before and after the extension and training activities

\begin{tabular}{lcccc}
\hline \multirow{2}{*}{ Knowledge Categories } & \multicolumn{2}{c}{ Before } & \multicolumn{2}{c}{ After } \\
\cline { 2 - 5 } & $\mathrm{n}$ & $\%$ & $\mathrm{n}$ & $\%$ \\
\hline Good & 4 & 12.9 & 16 & 51.6 \\
Medium & 12 & 38.7 & 8 & 25.8 \\
Lower & 15 & 48.4 & 7 & 22.6 \\
Total & 31 & 100.0 & 31 & 100.0 \\
\hline
\end{tabular}

Table 3 illustrates that there was an increase in the knowledge of participants after the outreach and training activities. The average value of the initial knowledge of the trainees was 64.69 , out of these scores $33.3 \%$ of the trainees had a value $<64.69$. Some participants were unable to answer correctly on questions number $1,4,5,14$, and15 from the questionnaire. Lack of knowledge can be influenced by the low level of education of respondents, whereas many as $35.5 \%$ of participants have education levels only up to elementary school. However, after counseling and training using the cooking demonstration method, some participants experienced an increase in knowledge so that the average value of the participants' final knowledge was 83.95. Increased knowledge can lead to changes in one's perceptions and habits because from experience and research it turns out behaviors that are based on knowledge will last longer than those that are not based on knowledge [11].

After the outreach and training activities are completed, an evaluation of the participants is carried out by asking the questions verbally. From the answers obtained from the training participants it can be concluded that the participants have tried to do more varied fish processing, and participants requested that they also are given training on processing lemuru fish with other variations, such as meatballs, fish balls, sausages, and so on.

\section{Conclusions}

Counseling and training activities in making lemuru nuggets can increase the knowledge of mothers who have stunting children in Pantai Labu Sub-District from an average value of $64.69 \%$ to $83.95 \%$. The increase in knowledge will be useful in preventing stunting in children through the provision of Lemuru fish nuggets, which can be produced by the mother of students. Lemuru nuggets have a protein content of $9.33 \%$ and minerals needed for growing children, such as $\mathrm{Ca}, \mathrm{Mg}, \mathrm{Zn}, \mathrm{Fe}$, and $\mathrm{P}$. 


\section{References}

[1] UNICEF, WHO, World Bank. Levels and Trends in Child Malnutrition. Joint Child Malnutrition Estimates. New York, NY: United Nations International Children's Fund; Geneva: WHO; Washington, DC: World Bank. Available from: http://www.who.int/nutgrowthdb/estimates/en/. 2012..

[2] C. P. Stewart, L. Iannotti, K. G. Dewey, K. F. Michaelsen, and A. W. Onyango, "Contextualizing complementary feeding in a broader framework for stunting prevention”. Maternal \& Child Nutrition, vol. 9, Suppl. 2, pp. 27-45, 2013.

[3] W. Z. A. Mikhail, H. M. Sabhy, H. H. El-Sayed, S. A. Khairy, H. Y. H. A. Salem, and M. A. Samy, "Effect of Nutritional Status on Growth Pattern of Stunted Preschool Children in Egypt". Academia Journal of Nutrition, vol. 2, no. 1, 2013.

[4] N. Setijowati, "Hubungan kadar seng serum dengan tinggi badan anak sekolah dasar penderita GAKI" [The relationship between the level of zinc serum and height on elementary school children with goiter]. Jurnal Kedokteran Brawijaya, vol. 21, no. 1, pp. 22-28, 2015.

[5] M. Sari, M. Juffrie, N. Nurani, and M. N. Sitaresmi, "Asupan Protein, Kalsium dan Fosfor pada Anak Stunting dan Tidak Stunting Usia 24-59 Bulan" [Intake of Protein, Calcium and Phosphorus in Stunting and Non-Stunting Children Ages 24-59 Months]. Jurnal Gizi Klinik Indonesia, vol. 2, no. 4, 2016.

[6] Kartini, Apoina, Suhartono, H. W. Subagio, Budiyono, I. M. Emman, "Kejadian Stunting dan kematangan Usia Tulang Pada Anak Usia Sekolah Dasar di Daerah Pertanian Kabupaten Brebes" [Stunting and bone-age maturity in elementary school students in agricultural areas of Brebes District]. Jurnal Kesehatan Masyarakat, vol. 11, no. 2, pp. 97-103, 2016.

[7] Health Research and Development Agency Republic Indonesia. LaporanRiset Kesehatan Dasar [Report of Basic Health Research]. 2013.

[8] S. Widodo, H. Riyadi, I. Tanziha, M. Astawan, "Perbaikan Status Gizi Anak Balita dengan Intervensi Biskuit Berbasis Blondo, Ikan Gabus (Channastriata), dan Beras Merah (Oryza nivara)" [Improving nutritional status of children under five year by the intervention of blondo, snakehead fish (Channastriata), and brown rice (Oryza nivara) based biscuit]. Jurnal Gizi Pangan, vol. 10, no. 2, pp. 85-92, 2015.

[9] D. Lestrina, O. Martony, N. Tarigan, "Pengaruh Pemberian Nugget Ikan Lemuru (Sardinella lemuru) Terhadap Asupan Protein, Zink, Kalsium dan Z Score TB/U Anak Sekolah Dasar yang Stunting di Wilayah Kerja Puskesmas Pantai Labu Kabupaten Deli Serdang”. [Effect of Provision of Lemuru (Sardinella lemuru) Fish Nugget on Protein, Zinc and Calcium Intake, and TB/U Score in elementry school children in working are of "Puskesmas" Pantai Labu Sub-District Deli Serdang Regency]. Report of "Hibah Bersaing" Research. Politeknik Kesehatan Medan. 2018.

[10] Departemen Perindustrian RI. The quality requirement of Nugget SNI 01-6683-2002. Jakarta. Industry Department of Republic Indonesia. 2002.

[11] S. Notpadmodjo, Promosi Kesehatan: Teori dan Aplikasi [Health promotion : Theory and Application]. Rineka Cipta: Jakarta. 2005. 